\title{
JOB ESTEEM ASSESSMENT OF FRONT OFFICE EMPLOYEES OF THE HOSPITALITY INDUSTRY
}

\section{Bharti Gupta*}

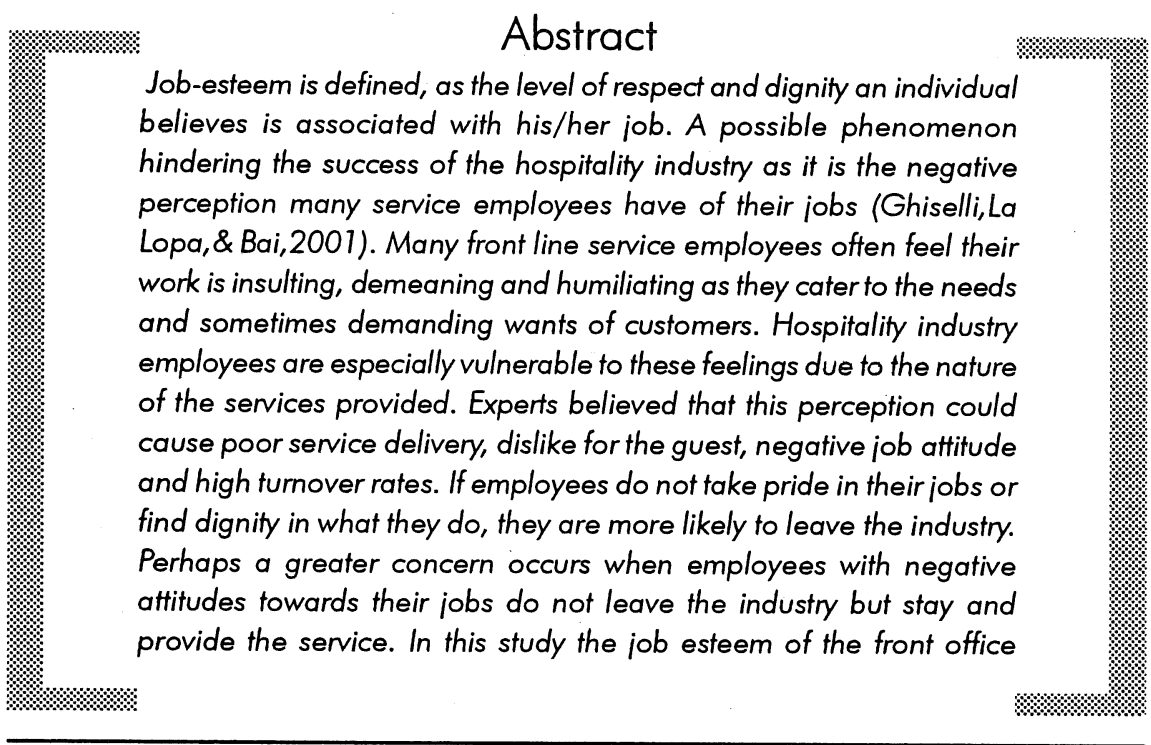

* UGC-NET-JRF, Centre for Hospitality and Tourism Management, University of Jammu, Jammu. Email: brgupt+@gmail.com 


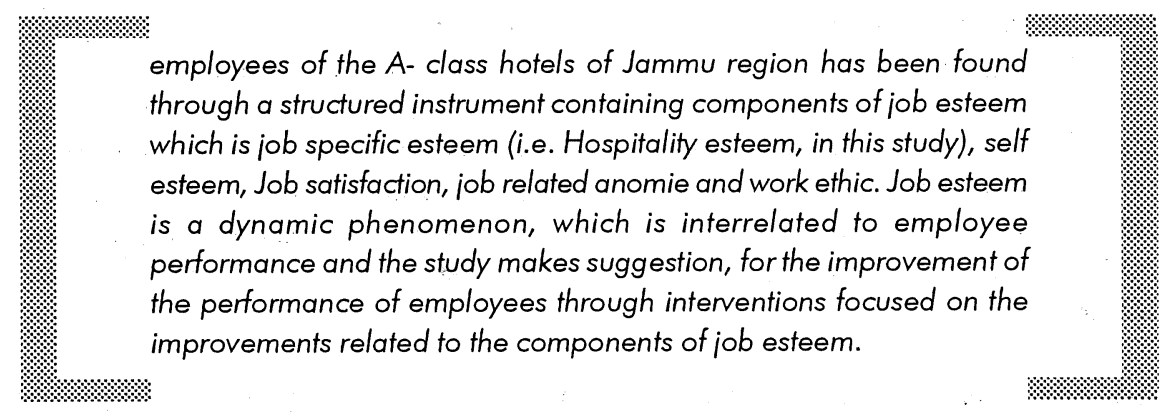

\section{Introduction}

Job esteem is defined as the level of respect and dignity an individual believes is associated with his/ her job. A possible phenomenon hindering the success of the hospitality industry is the negative perception many service employees have of their jobs (Ghiselli,La Lopa, \& Bai, 2001). Many front-line service employees often feel their work is insulting, demeaning, and humiliating as they cater to the needs and sometimes eccentric wants of customers. Hospitality employees are especially vulnerable to these feelings due to the nature of the service provided (Spillane, 2001). Experts (Bowen \& Lawler, 1995) believe that this perception could cause poor service delivery, dislike for the guest, negative job attitudes, and high turnover rates. If employees do not take pride in their jobs or find dignity in what they do, they are more likely to leave the industry. Perhaps a greater concern occurs when employees with negative attitudes towards their jobs do not leave the industry but stay and provide the service. The future success of the hospitality industry may rest in part with its ability to improve the image of service employment (Waryszak \& King, 2001).

Job esteem is the self analysis of the social value and dignity associated with one's job. Similar, but not synonymous concepts of self esteem, job satisfaction, work ethic and job related anomie are identified as components or contributing forces that influence job-esteem. The study of job-esteem is important to the hospitality industry because of the service nature of positions and the transient nature of many of the jobs. Many employees find cleaning guests' rooms, carrying guests' luggage, and serving guests' food to be demeaning and servile. This negative perception lowers employee job longevity. Understanding job-esteem would enhance the industry's ability to act on these issues through various organization development interventions including training. Job esteem would also be important for a variety of other service-related industries (e.g. health care, retail) that struggle with similar attitudes and performance issues and challenges. 
Job-esteem is proposed to be a global construct that is relevant in any industry. Therefore, for the concept to be effective in a measurement situation a unique set of items addressing the specific job studied must be included. For example, determining the job-esteem of hotel employees will require ascertaining attitudes to serving paying guests, whereas, the job-esteem of steel factory workers will require a unique set of items dealing with the manufacturing sector. In other industries the items may address different items. In this study, the hospitality esteem represents the job specific esteem.

Job Satisfaction. Job satisfaction is defined as "the emotional state resulting from the appraisal of one's job and as such can be negative, positive, or neutral" (Anvey, 1995, p. 273). Job satisfaction makes up a part of job-esteem, but these two concepts are not the same. There are four possible combinations of an individual's level of job-esteem and job satisfaction. First, it is possible for the job incumbent in a service role to have high job satisfaction but low job-esteem. This combination would seem to be the least likely of the four. An individual who perceives cleaning rooms for strangers as demeaning will have low job-esteem as a housekeeper at any hotel. However, this housekeeper is not precluded from having high job satisfaction because of low job-esteem. Many hotel companies go to great heights to improve satisfaction of employees by manipulating the work environment. It is possible for employees to ignore their feelings of low job-esteem if they have excellent work conditions, benefits, pay and supervision resulting in high job satisfaction. Secondly, it is possible for an employee to have high job satisfaction and high jobesteem. Emotionally and cognitively, the job holder who is highly satisfied with pay, benefits, supenvisors, and all other elements of job satisfaction will also be more likely to find the job to have elements of pride and dignity. Thirdly, some workers may experience low job satisfaction but also have high job-esteem. This relationship is not common but possible. A housekeeper may believe in caring for travelers and may value the role of providing the needed service. However, the housekeeper's job satisfaction may depend on factors such as work conditions, supervisors and co-worker relationships. In other words, this housekeeper with high job-esteem for housekeeping may not find job satisfaction at the Marriott Hotel but may be satisfied at the Hilton. Finally, workers may have low job satisfaction and low job-esteem. There is evidence that a large number of hospitality service sector employees have low job satisfaction (Barron \& Maxwell, 1998; Price, 1994).

Self-esteem. Self-esteem is defined as one's overall self-evaluation composed of respect, competence and worth (Cast \& Burke, 2002). It is the attitude individuals have about themselves as good or bad and whether they like themselves. People with high self-esteem are psychologically better adjusted, better students, better at handling criticism and better at coping with failure (Baron \& Bryne, 1991). When 
Tharenou (1979) evaluated self-esteem in a the work place, she found that high self-esteem was positively related to high job satisfaction and the intention to stay on the job. Job-esteem is similar to self-esteem because it encompasses the attitude, feeling and emotions that one has for his/her specific job. Respect and dignity associated with a job affects one's self-esteem and visa-versa, the level of one's self-esteem affects the level of respect and dignity that an individual associates with his/her job. Job-esteem may therefore, be considered a component of self-esteem as an individual's employment contributes to his/her overall self-esteem.

Another factor affecting job-esteem is Job-related anomie. Anomie is defined by traditional sociology as a negative social condition resulting from the collapse of values and norms. Individuals with anomie feel alienated, lack a sense of purpose and are confused about acceptable behavior (Durkheim, 1897/1951). Durkheim claimed thatanomie was a result of egoistic individualism. In other words, individuals with anomie focused on satisfying the ego or personal needs, while ignoring the needs of the group (Kendall, 1996). However, Durkheim proposed a solution for anomie. He reasoned that combining the individual needs with the group (or society's) needs would satisfy the identity of the individual and the need for group norms and values. Job-related anomie is defined as the level of an employee's belief that his or her organization is void of values and norms. Work Ethic is also one of the components of job esteem. Many definitions of work ethic exist; most notable is the Protestant work ethic, which implies a religious obligation to work hard-a commandment from God (Grenholm, 1993). This concept was first proposed by Weber in 1905 and has undergone exhaustive study ever since. Furnham (1987) defined work ethic as "dispositional variable characterized by a belief in the importance of hard work, rationality, and frugality which acts as a defense against sloth, sensuality and religious doubt" (p. 383). Work ethic has been used as an index of job satisfaction (Pietrofesa \& Splete, 1975), providing a theoretical connection to job-esteem. Job-esteem is expected to be associated with work ethic because work in itself is a source of pride for some workers. For workers with a traditional work ethic, it may not matter what job they do; the key point is that they are, working.

In this study the job esteem of the front line employees of the A- class hotels of Jammu region has been found through a structured instrument containing components of job esteem which are job specific esteem (i.e. Hospitality esteem, in this study), self esteem, Job satisfaction, job related anomie and work ethic. Since job esteem, a dynamic phenomenon, is interrelated to employer performance, the study makes suggestion for the improvement of the performance of employees through interventions focused on the improvements related to the components of job esteem. 


\section{Hypothesis}

The job esteem of the front line employees of the hospitality industry is low

\section{Objectives}

1. To assess the components namely hospitality esteem, self esteem, job satisfaction, job related anomie and work ethic of the front office employees in order to determine their job esteem.

2. To identify the component that is more effective in influencing the job esteem.

3. To suggest various measures improving the job esteem in frontline employees of the hospitality industry.

\section{Research Methodology}

The universe of the study includes all the A class hotels of Jammu city of Jammu region. In all there are six A class hotels in Jammu city. These are Hotel Asia, K.C Residency, The Fortune Riveria, Jhelum Resort, Hari Niwas Palace and The Hotel Ashok.

Primary data collection has been done with the help of a structured questionnaire developed by Douglas G Miller and Susan R. Madsen. The front office staff of each hotel was approached for filling the questionnaire. The number of respondents varies among the hotels. All the front office employees of each hotel were approached. The total number of respondents covered in the study is 25 . The questionnaire comprises of 35 statements. These 35 statements are sub divided into five main heads namely Hospitality Esteem, Self Esteem, Job satisfaction, Job related Anomie and Work Ethic. These main headings were not revealed in the questionnaire for data collection so as to remove the element of bias from the respondents. Information is collected against these parameters with the help of five point likert scale having scores ranging from 1 to 5 , where score 1 represents highly disagree, 2 represents disagree, 3 represents neither agree nor disagree, 4 represents agree and 5 represents highly agree. 


\section{Data interpretation and Analysis}

\section{Table 1}

\begin{tabular}{|l|l|c|}
\hline S.No. & Name of hotels & $\begin{array}{c}\text { Number of front office } \\
\text { employees working in the hotel }\end{array}$ \\
\hline 1 & Asia & 4 \\
\hline 2 & Jhelum & 3 \\
\hline 3 & Ashoka & 3 \\
\hline 4 & Residency & 4 \\
\hline 5 & The Fortune Raveria & 6 \\
\hline 6 & Hari Niwas & 5 \\
\hline
\end{tabular}

\section{Table 2}

\begin{tabular}{|c|c|c|c|}
\hline $\begin{array}{l}\text { S. } \\
\text { No. }\end{array}$ & $\begin{array}{l}\text { Main heading with } \\
\text { the respective } \\
\text { mean values }\end{array}$ & Statements & Mean \\
\hline \multirow[t]{6}{*}{1} & \multirow{6}{*}{$\begin{array}{c}\text { Hospitality Esteem } \\
4.193\end{array}$} & Serving visitors give me pride & 4.36 \\
\hline & & I am embarrassed if my friends see me & 1.68 \\
\hline & & Hotel work is demeaning & 1.36 \\
\hline & & l encourage friends to get hotel jobs. & 3.6 \\
\hline & & Caring for hotel guests is rewarding & 3.52 \\
\hline & & Hotel guests see me as a paid servant. & 1.28 \\
\hline \multirow[t]{5}{*}{2} & \multirow{5}{*}{$\begin{array}{c}\text { Self esteem } \\
4.488\end{array}$} & I have not done much to deserve pay & 1.4 \\
\hline & & I have good qualities that help in my job & 4.84 \\
\hline & & I am as valuable as any other employee & 3.88 \\
\hline & & I am not proud of my job performance & 1.24 \\
\hline & & I feel useless at work & 1.64 \\
\hline
\end{tabular}


Table-2 (contd.)

\begin{tabular}{|c|c|c|c|}
\hline S. & $\begin{array}{l}\text { Main heading with } \\
\text { the respective } \\
\text { mean values }\end{array}$ & Statements & Mean \\
\hline \multirow[t]{11}{*}{3} & \multirow{11}{*}{$\begin{array}{c}\text { Job satisfaction } \\
4.112\end{array}$} & My job is enjoyable & 4.04 \\
\hline & & I am paid fairly & 1.64 \\
\hline & & My supervisor is competent & 4.2 \\
\hline & & I receive recognition for good work & 4.4 \\
\hline & & My supervisor is unfair to me & 1.28 \\
\hline & & I do not feel appreciated & 1.92 \\
\hline & & I work harder due to others incompetence & 1.52 \\
\hline & & I like doing the things I do at work & 4.84 \\
\hline & & $\begin{array}{l}\text { My supervisor shows little interest in } \\
\text { employees }\end{array}$ & 1.28 \\
\hline & & I enjoy with my co-workers & 4.12 \\
\hline & & I feel a sense of pride in my job & 4.04 \\
\hline \multirow[t]{3}{*}{4} & \multirow{3}{*}{$\begin{array}{l}\text { Job related Anomie } \\
\quad 4.213\end{array}$} & Managers are not interested in workers & 1.56 \\
\hline & & Work conditions are getting worse & 1.88 \\
\hline & & Workers do not know who to depend on & 1.92 \\
\hline \multirow[t]{10}{*}{5} & \multirow{10}{*}{$\begin{array}{l}\text { Work Ethic } \\
4.2\end{array}$} & If you try hard enough you can get ahead. & 4.8 \\
\hline & & $\begin{array}{l}\text { Most employees go out of their way to } \\
\text { help. }\end{array}$ & 3.36 \\
\hline & & I feel my job is meaningless & 1.84 \\
\hline & & Being a hospitality employee is fulfilling & 3.84 \\
\hline & & A good employee values a job well done. & 3.56 \\
\hline & & Dignity exists in hard work. & 4.96 \\
\hline & & $\begin{array}{l}\text { I should give my best effort regardless } \\
\text { of the job }\end{array}$ & 4.24 \\
\hline & & Work is worthwhile only if it earns respect & 4.32 \\
\hline & & I take pride in the quality of my effort & 4.36 \\
\hline & & I seek personal fulfillment from work & 4.4 \\
\hline
\end{tabular}


The table 1 shows the name of the A class hotels surveyed in the study as well as the number of the front office employees covered from each hotel. Table 2 represents mean value for each of the main headings as well as the mean value for each statement falling under the main headings. The mean for each main heading is calculated by applying arithmetic mean on all the mean values of the statements falling under each statement. The table shows that the front office employees have high level agreement with the self-esteem (4.48) aspects followed by job related anomie (4.21), work ethic (4.2), hospitality esteem (4.19) and job satisfaction (4.11).

Under the main heading Hospitality Esteem, the mean value score for the statements serving visitors gives me pride (4.36), I encourage friends to get hotel jobs (3.6), caring the hotel guests is rewarding (3.52) reveals that the attitude of the front office staff is quite positive for their jobs. The mean values under the same main heading for the statements I am embarrassed if my friends see me (1.68), hotel work is demeaning (1.36) hotel guests see me as a paid servant (1.28) further reveals a positive attitude as the statements are negative in approach. If these statements are given inverse score to reveal positive then the values are 4.32 , 4.64 , and 4.72 respectively. Under the main heading self esteem, the mean values for the statements- I have good qualities that help me in my job (4.84), I am as valuable as any other employee (3.88), show that employees are positively oriented for these aspects identified under the self esteem.

The statements, under the same heading, I have not done much to deserve to pay (1.4), I am not proud of my job performance (1.24) I feel useless at work (1.64) show that disagreement of the respondents for these negatively oriented statements thereby showing positive approach of the front office employees towards their self esteem in the context of their jobs. If inverse scores are given to these negatively oriented statements to reveal the positivity of the respondents then the values are $4.6,4.76$ and 4.36. Under the main heading Job satisfaction, the mean values for the statements, my job is enjoyable (4.04), my supervisor is competent (4.2), I receive recognition for good work (4.4), I like doing the things I do at work (4.84), I enjoy with my co workers (4.12), I feel a sense of pride in my job (4.04) show the agreement of employees towards job satisfaction aspects. The disagreement for the statements I am fairly paid. (1.64) reveals that they are not satisfied with this parameter of job satisfaction. However the statements my supervisor is unfair to me (1.28), I do not feel appreciated (1.92), I work harder due to others incompetence (1.52) and my supenvisor shows little interest in employees (1.28) shows that the employees keep disagreement with these negatively oriented statements and thus denouncing them and favoring their opposites. The inverse scores to these statements have the values $4.68,4.08,4.48,4.72$ respectively. Under the main heading job related 
Anomie, the mean values below 3 for the statements, managers are not interested in workers (1.56), work conditions are getting worse (1.88), and workers do not know who to depend on (1.92) reveal the disagreement of the employees for any work related anomie in their organization. The inverse scores to these statements have the values $4.44,4.12$, and 4.08 respectively. Anomie is defined by traditional sociology as a negative social condition resulting from the collapse of values and norms. Under the main heading work ethic there are ten statements. Out of these ten statements, the mean values for nine statements which are if you try hard enough, you can get ahead (4.8), most employees go out of their way to help (3.36), Being a hospitality employee is fulfilling (3.84), a good employees values a job well done (3.56), Dignity exists in hard work (4.96) I should give my best effort regardless of the job (4.24), work is worth while only if it earns respect (4.32), I take pride in the quality of my effort (4.36) and I seek personal fulfillment from work ( 4.4 ) are all above three. This shows that work ethic exists in the hospitality sector units of the Jammu city.

Under the work ethic heading only one statement- I feel my job is meaningless (1.84) is having value lower than 3 . But this value corresponds to their disagreement for the statement that is negatively loaded. The inverse score to this statement has value of 4.16 .

\section{Table 3}

\section{Coefficients}

\begin{tabular}{|c|c|c|c|}
\hline & $\begin{array}{c}\text { Standardized } \\
\text { Coefficients } \\
\text { Beta }\end{array}$ & $T$ & Sig. \\
\hline Model & & -.040 & .969 \\
I(Constant) & .425 & 2.202 & .040 \\
SE & .426 & 2.241 & .037 \\
JS & -.613 & 2.696 & .014 \\
JRA & .171 & .741 & .467 \\
WE & &
\end{tabular}

a Dependent Variable: HE 
Table 3 is the regression result of the main headings where hospitality esteem (HE) is the dependant variable and self esteem (SE), Job satisfaction (JS), job related anomie (JRA), and work Ethic (WE) are the independent variables.

The significant values clearly show that $\mathrm{HE}$ is significantly related to $\mathrm{SE}$, JS and JRA where as $\mathrm{HE}$ is insignificantly related to WE as the value is greater than .05 level of significance

The regression equation that can be derived from this table is as below

$\mathrm{HE}=-.748+.425 \mathrm{SE}+.426 \mathrm{JS}+(-.613) \mathrm{JRA}+.171 \mathrm{WE}$

The above regression equation shows that unit change in hospitality esteem of a front office employee is affected $42 \%$ by the self esteem of the employee, $42 \%$ by the job satisfaction, $61 \%$ by the job related anomie and $17 \%$ by the work ethic.

\section{Suggestion and Conclusion}

The study reveals that the front office employees of the A-class hotels of Jammu are having a very positive approach towards their job. Throughout the study all the positive statements received agreement and all the negative statements received disagreement with the exception of one statement that is "I am paid fairly." The mean value to this statement is 1.64 . This shows that there is high disagreement with this aspect related to the job satisfaction. Owing to such results, the hypothesis that the job esteem of the front line employees of the hospitality industry is low can be rejected.

The regression equation clearly shows that it is Job related anomie that is most affecting hospitality esteem, though the relation is not direct but inverse.

To suggest measures in improving the job esteem of frontline employees in the hospitality industry, it could be said that for high job satisfaction the industry employees must be fairly paid. It is very important to raise the salary of the front office employees from the current level, as salary is the core issue for any employee. Hence salary is an important component of job satisfaction.

\section{References}

- Arvey, R.D. (1995). Job Satisfaction. In N.Nicholson (Ed.), Encyclopedia dictionary of organizational behavior (pp.272-274). Cambridge, MA: Blackwell Publishers.

- Baron, R.A.,\& Bryne,D. (1991). Social psychology. Needham Heights, MA:Allyn \& Bacon. 
- Barron, P., \& Maxwell.G. (1998). Employee job perception: A Comparison of Scottish and Australian fast food units. Australian Journal of Hospitality Management, (1), 33-41.

- Bowen, D.E., \& Lawler, E.E. (1995). Empowering service employees: What,Why, How, and When. Saloan Management Review,36, 73-84.

- Cast, A.D., \& Burke, P.J. (2002). A theory of Self esteem. Social Forces, 80 (3),1041-68

- Durkheim, E. (1951). Suicide (J.A. Spaulding \& G. Simpson, Trans). New York: Free Press. (Original work published 1897).

- Furnham, A. (1987). Protestant work ethic beliefs. European Journal of Personality, 1,93-106

- Ghiselli, R.F.,La Lopa, j.M., \& Bai,B. (2001). Job Satisfaction, life satisfaction, and turnover intent: Among service managers. Cornell Hotel and Restaurant Administration Quarterly, 42 (2),28-37.

- Grenholm, C. (1993). Protestant work ethics: A study of work ethical theories in contemporary protestant theology Coronet Books.

- Kendall, D.E. (1996). Sociology in our times. Belmont : Wadsworth.

- Pietrofesa, J.J. \& Splete, H. (1975). Career development: Theory and research New York:Grune and Stratton.

- Price, L. (1994). Poor personnel management in the hotel and catering industry: Does it matter? Human Resource Management Journal, 4(4),44-61.

- Spillane, J.J (200.1). The Christian humanization of work: job satisfaction in the hospitality industry. Revised Business, 22 (3), 16-23.

- Tharenou, P. (1979) Employee self-esteem: A review of the literature. Journal of Vocational Behavior, 15,316-346.

- Waryszak, T., \& King, B. (2001). Managerial attitude towards work activities in the hospitality and service industries. International jounal of Contemporary Hospitality Management, 13 (4/5), 197-204. 